\title{
Effect of Melia azedarach L. and Ailanthus altissima Swingle Extracts on the Larva Alimentary Tract and Growth of Black Cutworm, Agrotis ipsilon Hufn. (Lepidoptera: Noctuidae)
}

\author{
Atallah F. Mekhlif \\ Department of Biology \\ College of Education \\ Mosul University \\ dr_atallah1957@yahoo.com
}

(Received 15/10/2008; Accepted 26/1/2009)

\begin{abstract}
The enriched methanolic extracts of seeds of Melia azedarach and leaves of Ailanthus altissima have had the same effect on the valves of the cardiac sphinector of Agrotis ipsilon larvae. At the low concentrations, the sphinector was expanded, and the valves degenerated at the high concentrations. $M$. azedarach extract was separated the peritrophic membrane and muscles of the midgut, while the extract of $A$. altissima was thicked the peritrophic membrane only. The application of extracts were effected on developed pupae and adults of treated larvae, this effect was represented by failure of adults emergence and degrees of wings malformations. Also, the extracts were significantly reduced the weight of $A$. ipsilon larvae fed on treated diets. For treated larvae, $\mathrm{Lc}_{50}$ of black cutworm larvae were 2.5 and 3.5 ppm for M. azedarach and A. altissima respectively.
\end{abstract}

Keywords: Agrotis ipsilon, Melia azedarach, Alilanthus altissima, malformation, mortality.

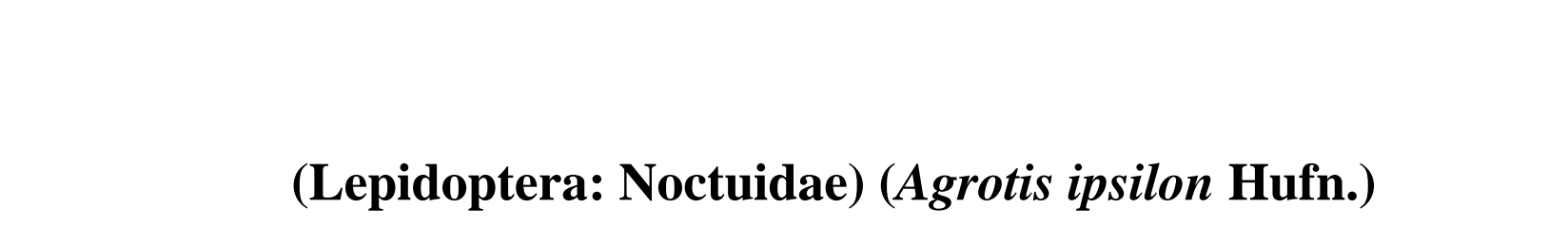

\section{الملهص}

يؤثر المستخلص الميثانولي المركز لب ذذور ال سبحيح Melia azedarch وأوراقش هجرة الجنة تأثيرَّمتشابهاَ في الصمه القلبي ليرقلت الدوة القارضة للسوداء، اذ توسع الصملم

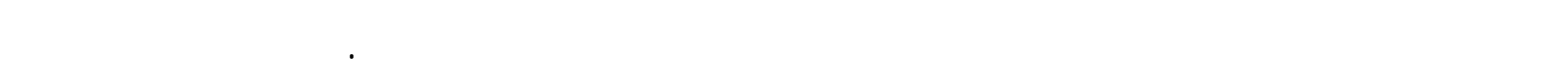
للسبحس افقصل الغشاء حول الغذاء والعضلات للمعي الأوسط بينما مستخلصشيجرة الجنة زادم ـنس مك الغثاء حول الغذاء فتط. أثرت المعلملة بالمستخلصت في ظطور العذارى والبالغلت المعلل غذاء اليرق لت المظورة عنها بالمستخلصت. وقد تمل هذا التأثير بهثل بُزوغ البالغلت ودرجلت من تشوه تلك البالغ لت، 


\section{كما قص وزن اليرقت المعلملة معنوياً، وقد بلغت قيمة Lc50 ليرقت الدوة القارضة السوداء 2.5 و 3.5 جزء في المليون لبذور للسبحح وأوراقشجرة الجنة على التوالي.}

\section{INTRODUCTION}

Plants produce a variety of secondary metabolites, some of them in a significant amounts which are interfere with growth and development of phytophagous insects, therefore, application of the insect's diet with sublethal doses of these bioactive ingredients will cause mortality and abnormal progenies.

Chinaberry tree Melia azedarach L., is one of the important known species in the family meliaceae because it is rich in triterpenoids and limonoids (Srivastava and Gupta, 1985; Ascher et al, 1995; Huang et al., 1995; Nakatani et al., 1998). The extract of the different parts of $M$. azedarch have various effects on the developed insects of different orders, especially lepidoptera, when the larval diets treated with low concentrations of the plant extract, e.g. prolongation of egg, nymph and larval periods (Cespedes et al., 2000; De'Souze and vendramm., 2000; Mekhlif, 2004), antifeedant and failure of adult emergence (Carpinella et al., 2003), endocrine effects (Schmidt et al., 1998), and malformation of immature stages and adults (Schmidt et al., 1997 ; Al-Hamadani, 2002) and antimolting of immature stages (Cabral et al., 1996).

Tree of heaven, Ailanthus altissima (Mill.) Swingle (glandulosa Desf.) belongs to Quassia family (Simaroubaceae) (Sandor and Vera, 1979) was introduced to Mosul city in Iraq since about one decade as ornamental tropical tree, and cultivated in Mosul forest and other city areas. Extracts of A. altissima includes quassinoid triterpenoids, ailonthone, amarolide, acetyl amarolide and 2-dihydroxy ailanthone (Casinovi et al., 1983; Aono et al., 1999). The aqueous extract of A. altissima leaves have insecticidal and herbicidal activities (Heisey, 1996; Tsao et al., 2002) and have been used to control insects such as Pieris rape and Platyedra gussyaella (Yang and Tang, 1988).

Black cuturom, Agrotis ipsilon Hufn. is one of notorious migrant pests in Iraq, it infest many plants in Iraq such as, cabbage, beet, lettuce, etc. It is multivoltine (Wiltshire, 1957). Application of enriched methanolic extract of $M$. azedarach with concentrations ranged between 10 and $100 \mathrm{ppm}$ had been effected on larval growth parameters of A. ipsilon (Schmidt et al., 1997; Schmidt et al., 1998).

The purpose of this work was to evaluate the effect of enriched extracts of $M$. azedarach and A. altissima on some biological aspects and to investigate influence of the extract active compounds on functional tissues of treated larvae and other developed stages.

\section{Insects}

\section{MATERIALS AND METHODS}

The flying fertalized females of Agrotis ipsilon were captured by handle net around fluorescence light in the garden houses during early June, the time of passing migratory months in Mosul city in Iraq. The captured females fed on 15\% honey solution in the suitable insetory. Filter paper strips were put for egg laying.

In order establishment the colony, the patches of the eggs were removed and incubated for two days, at $27 \pm 1{ }^{\circ} \mathrm{C}, 60 \%$ relation humidity and $16: 8$ day time conditions the hatching neonate larvae fed on artificial diet (Al-Hamadani ,2002 ; Mekhlif ,2004). 
After pupation, the pupae were sexually isolated for adults emergence.

\section{Preparation of the extract}

The unripe fruits of chinaberry were collected at the late October, washed and frozen. Leaves of heaven of china tree were washed and dried in the shade through June and ground with a coffee mill to a dry powder. The chinaberry unripe fruits were grounded by mortar.

To prepare the enriched extract, $50 \mathrm{gm}$ of each A. altissima leaves powder and unripe fruits ground of $M$. azedarach were separately macerated with $150 \mathrm{ml} 80 \%$ methanol for 24 hours. These extracts were transferred into a glass beaker, then, each extract was stirred for 6 hours and filtered under low pressure. The dry extract was redissolved in $80 \%$ methanol in separating funnel and washed with the same volume of petroleum ether (B.p. $30-35{ }^{\circ} \mathrm{C}$ ) by hand shaking for half an hour. The extract was separated into two layers; the methanol extract was dried as formerly described, and washed with equal volumes of distilled water and ethyl acetate in a separating funnel. The ethyl acetate extract was released and dried. Then, the dry extracts were weighted and redissolved in $80 \%$ methanol to prepare a stock solution.

\section{Preparation of the larvae for treatments}

All the experimental applications were conducted with third instar larvae. The larvae were fasted for six hours before they fed on treated diets, by placing them in large container to avoid cannibalism behavior.

The third in star larvae were kept singly in a plastic container $(\mathrm{d}=10 \mathrm{~cm}, \mathrm{~h}=30 \mathrm{~cm})$ with circular piece of about 20 gm of the treated diet, the diet piece was refreshed every two days.

\section{Extract effect estimation}

The effect of the extracts on treated larvae were estimated through adults malformations by sublethal doses less than $25 \mathrm{ppm}$ and larval mortality thought 50 larvae for each treatment. Also, the effect of the extracts were investigated at the level of tissues deterioration of the treated larva digestive system. Tissues preparations and staining protocol were conducted after, Ewen (1962) and Mekhlif (2004).

\section{Extract effect on mortality and weight}

\section{RESULTS AND DISCUSSION}

Fig. (1) was showed the mortality of Agrotis ipsilon larvae which their diet treated with different concentrations of enriched Melia azedarach and Ailanthus altissima extracts. The effective concentration $\mathrm{Ec}_{50}$ (the concentration of the extract which causes mortality of $50 \%$ of treated larvae) of $M$. azedarach and A. altissima were 2.7 and 3.5 ppm respectively. The applied concentrations: $1,5,10$ and $15 \mathrm{ppm}$ were approximately caused similar black cutworm mortality either for unripe $M$. azedarach nor leaves A. altissima. But the later two concentrations: 25 and $50 \mathrm{ppm}$ of $A$. altissima were more effective in relation to the same concentrations of $M$. azedarach extract.

The mechanism of larval mortality when the diets treated with chinaberry and tree of heaven extracts at the concentrations 1, 5, 10 and $15 \mathrm{ppm}$ was attributed to the similarity of metabolic pathways of limonoid and quassinoid triterpenoids which extracted from chinaberry and tree of heaven respectively (Casinovi et al., 1983; Srivastava and Gupta, 1985; Ascher et al, 1995; Huang et al., 1995; Nakatani et al., 1998; Aono et al., 1999). It 
was concluded from Fig. (1) the additional concentrations of quassinoids and other specific ingredients of tree extract of heaven would proportionally increased the mortality of treated larvae up to $98 \%$ at the concentration $50 \mathrm{ppm}$. In comparison between the larval mortality for the last two concentrations 25 and $50 \mathrm{ppm}$, the mortality was increased from 82 to $86 \%$ for $M$. azedarach, while that of A. altissima increased from 72 to $98 \%$, so that, the mortality was multiplied more than six folds between the applied extracts at the concentrations 25 and 50 ppm (Fig 1).

The results in the table 1 shows that all the applied concentrations; 1, 10, 25 and 50 ppm were significantly reduced the weight of treated larvae of A. ipsilon. Also, the treated larvae were more affected by $M$. azedarch extract than A. altissima extract.

\section{Malformation effect of the extracts}

Generally, the normal newly emerged insect was characterized by curled wings, but with advanced time, the wings were expanded till they took usual appearance However, in the present study, after pupation, there was percent of emerged adults their wings varied between severely curled and folded with different degrees (Plate 1).

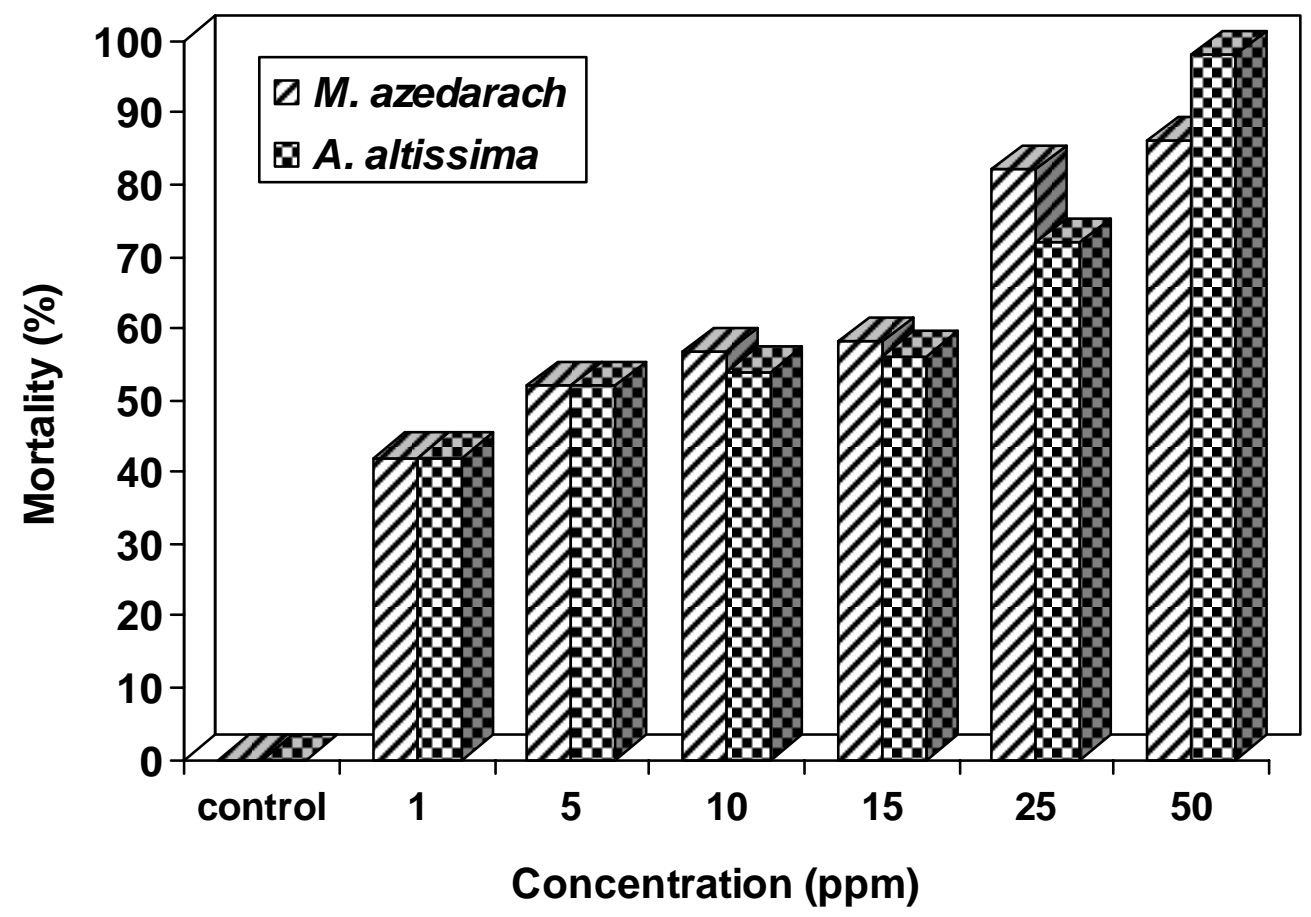

Fig. 1: Mortality of Agrotis ipsilon larvae, diet was treated with the extracts M. azedarach unripe fruits and leaves A. altissima

Table 1: Effect of Melia azedarech and Ailanthus altissima extracts on weight of Agrotis ipsilon treated larvae (mg)

\begin{tabular}{|c|c|c|c|c|c|}
\hline \multirow{2}{*}{ Plant extract } & \multicolumn{5}{|c|}{ Concentration (ppm) } \\
\cline { 2 - 6 } & 0 & 1 & 10 & 25 & 50 \\
\hline M. azedarach & $412 \mathrm{a}$ & $338 \mathrm{c}$ & $306 \mathrm{~d}$ & $274 \mathrm{e}$ & $219 \mathrm{f}$ \\
\hline A. altissima & $412 \mathrm{a}$ & $362 \mathrm{~b}$ & $340 \mathrm{c}$ & $302 \mathrm{~d}$ & $289 \mathrm{de}$ \\
\hline
\end{tabular}


Note: Means followed by the different letters are significantly different according to Duncan's multiple range test $(\mathrm{P}<0.01)$

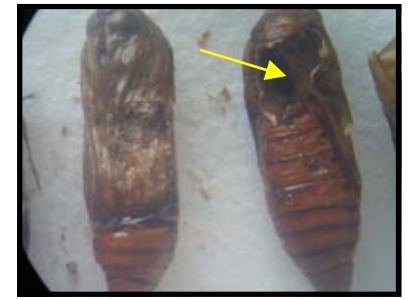

a
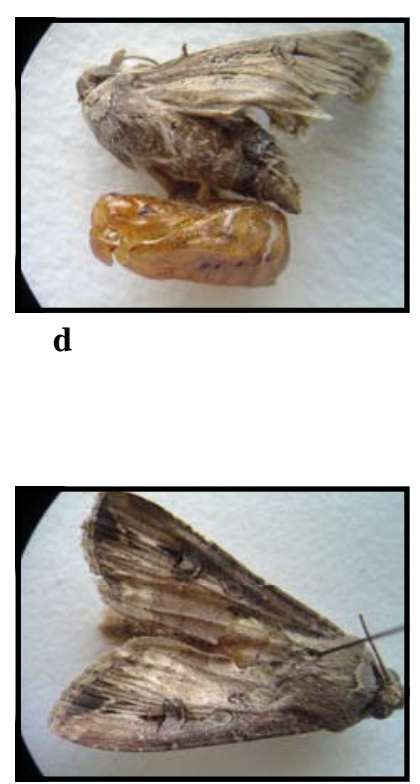

g

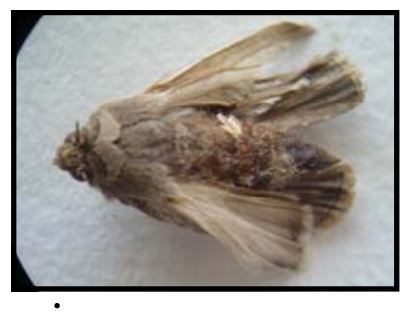

j

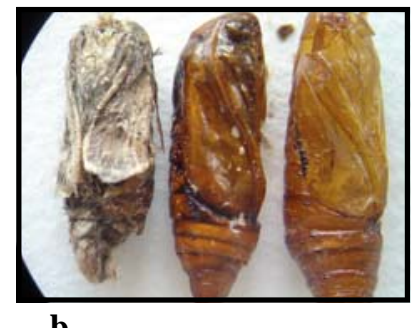

b

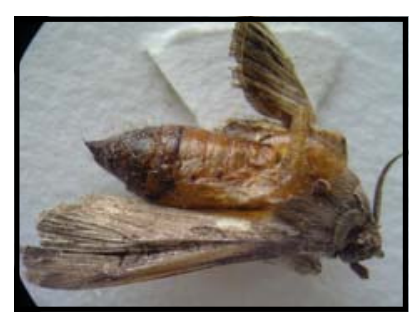

e

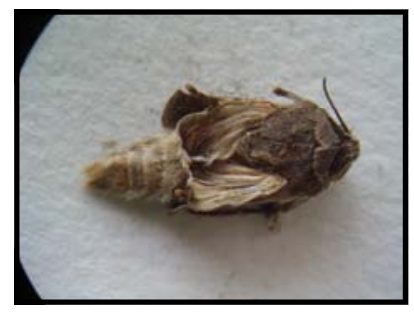

h

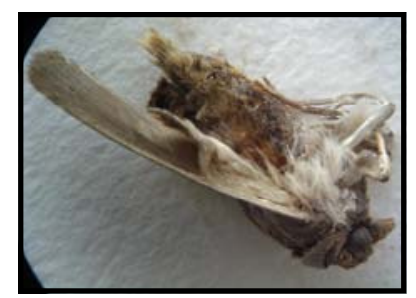

$\mathbf{k}$

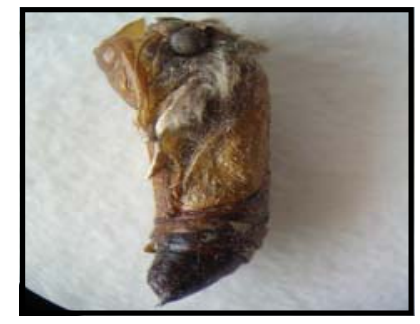

C

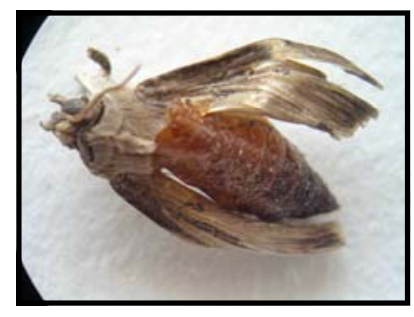

f
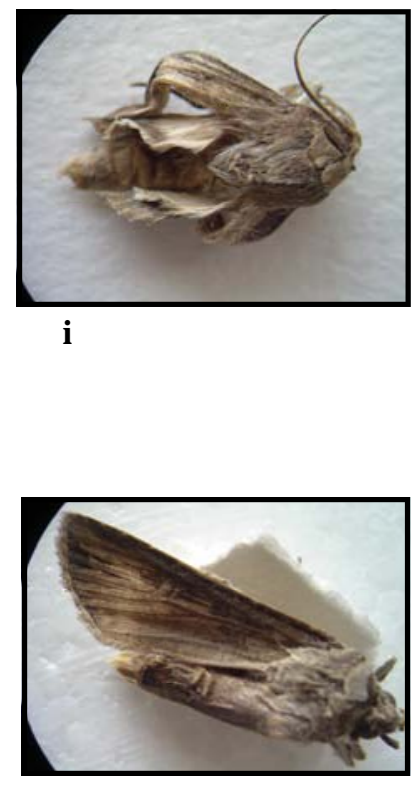

l

Plate 1: Pupae and adults of Agrotis ipsilon which had been treated at larvae stage with different concentrations of Melia azedarach and Ailanthus altissima extracts

$\mathrm{a}, \mathrm{b}$, and c- are pupae stage with different emergence failure.

d,e, and f- represent puparium adhesion.

g- Control.

$\mathrm{h}$ and i- are adults with curly wings.

j- conversion of wings.

$\mathrm{k}$ - hind wings vestigial.

l- malformed right wings. 
The malformed adult wings when larval stage feeding on diet treated with $M$. azedarach and A. altissima extracts is apparently belong to unsufficient hemolymph hydrolyic pressure to ensure complete wings expandence.

Also, Plate 1 illustrates that complete or part of puparium was adhesived to adult abdomen or other its appendages. Eclusion is depend on the rate of polypeptide and ecdyson hormones (Begley et al., 2005), in this manner, the effective ingredients of the extracts were eliminate the role of eclusion hormones through denaturation of eclusion hormone or reducing the hormones titer in the hemolymph, other studies were found that triterpenoid azedarchtin group effected hormones titer in the hemolymph (Barynby and Klocke, 1990).

On the other hand, completed failure of emergence was found in spite of full grown pupae, the causative of this failure as well as previous resions, was the triterpenoids which multiplied the thickness of the integument (Mekhlif, 2004), so that, preventing the formation of ecdysial lines through pupation.

The dried liquid contents of the pupa means the applied extracts of chinaberry and tree of heaven prevents the pathways of histolysis and histogensis for the developed treated pupae (Plate. 1a).

For each treatment at the concentrations 10, 15 and $25 \mathrm{ppm}$ of A. altissima extract, the percent of the eclusion failure parameter was more than $40 \%$ while that of undeveloped pupa was approximately one third of examined pupae. The curled and adhesived puparium parameters were only recorded for $1 \mathrm{ppm}$ treatment. Also, it was not found significant differences between the effect of chinaberry and tree of heaven extracts on the studied parameters except for undeveloped pupae, which was less recording at the concentrations 10, 15 and 25 ppm for chinaberry extract (Fig. 2,3).

\section{Effect on cardiac spninictor}

Plate 2a shows the longitudinal section of control larva at the junction between crop and midgut. The valves between crop and midgut is control food passing between these two parts of digestive tract of Lepidoptera through interval opening of this valve (Richards and Davies, 1978). Treatment of the feeding diets with low concentrations (1, 5, 10 and $15 \mathrm{ppm})$ of $M$. azedarach was disrupted the valves function, and they were continuously still opened (Plate 2b). But the sections of the larvae which their diets treated with 25 and $50 \mathrm{ppm}$ of $M$. azedarach were appeared significant reduction of the valves size and lost its ability to control food passing between crop and midgut (Plate 2c). 


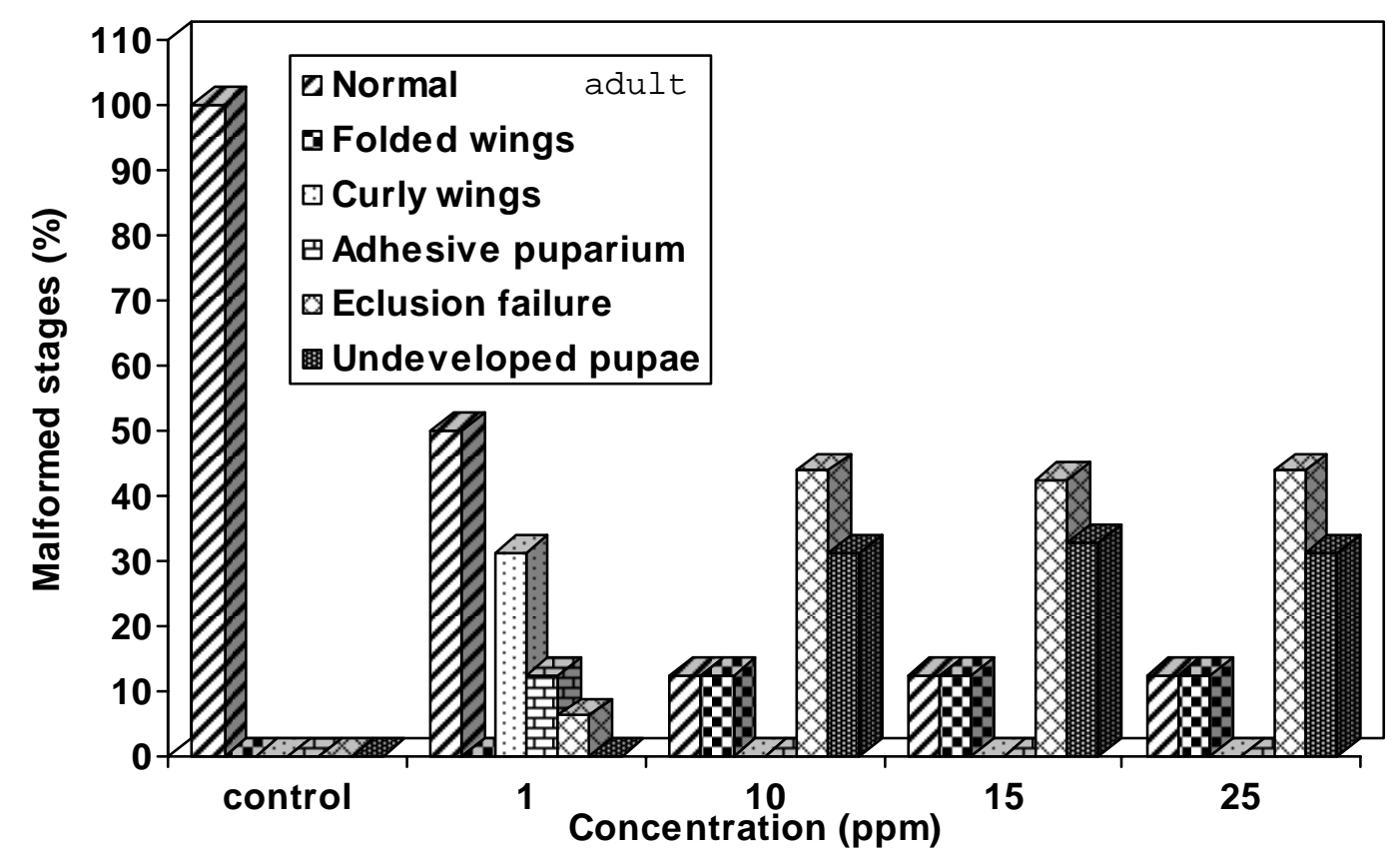

Fig. 2: Effect of the M. azedarach unripe fruits extract on emergence of A. ipsilon (\%)

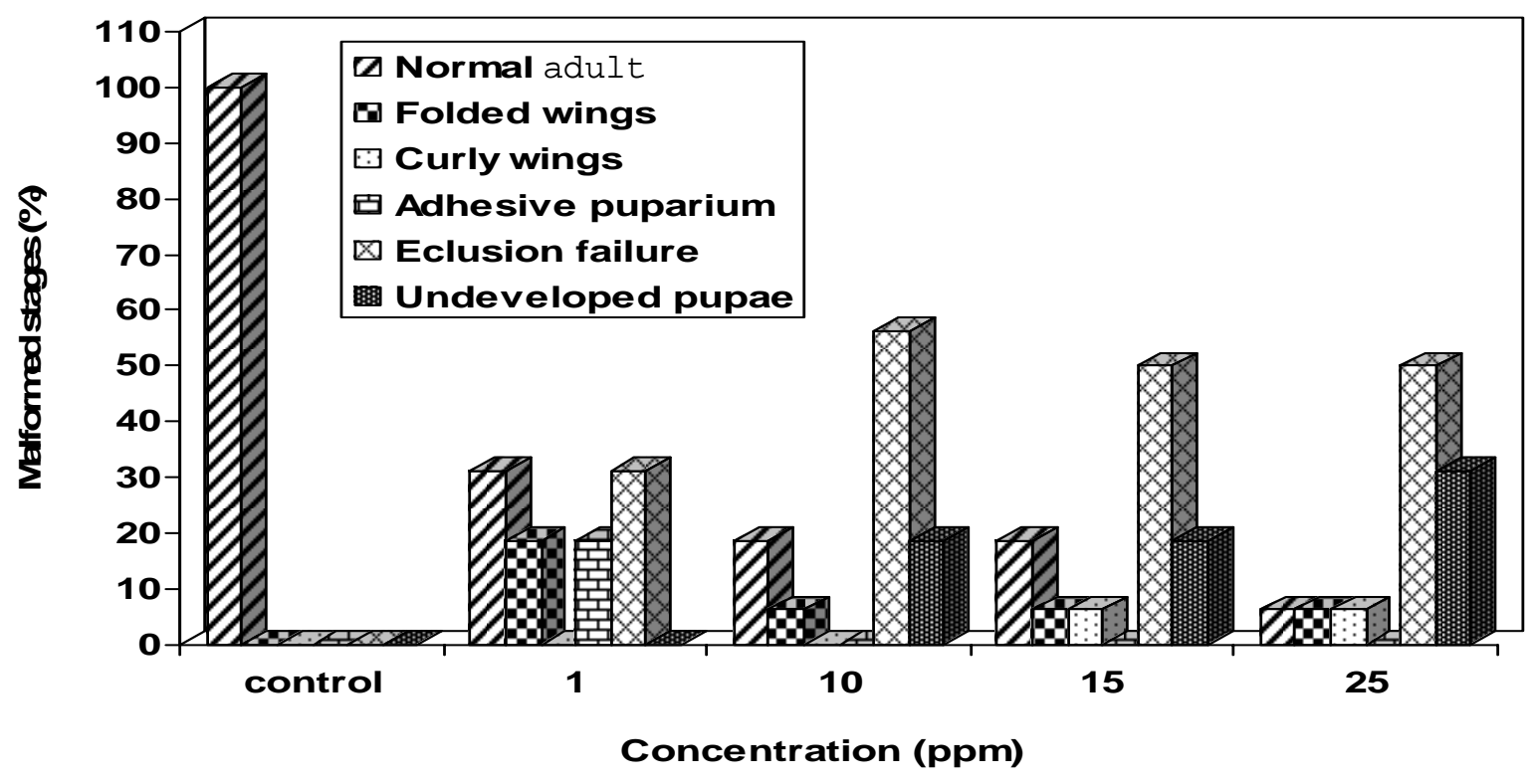

Fig. 3: Effect of the A. altissima leaves extract on emergence of A. ipsilon (\%) 

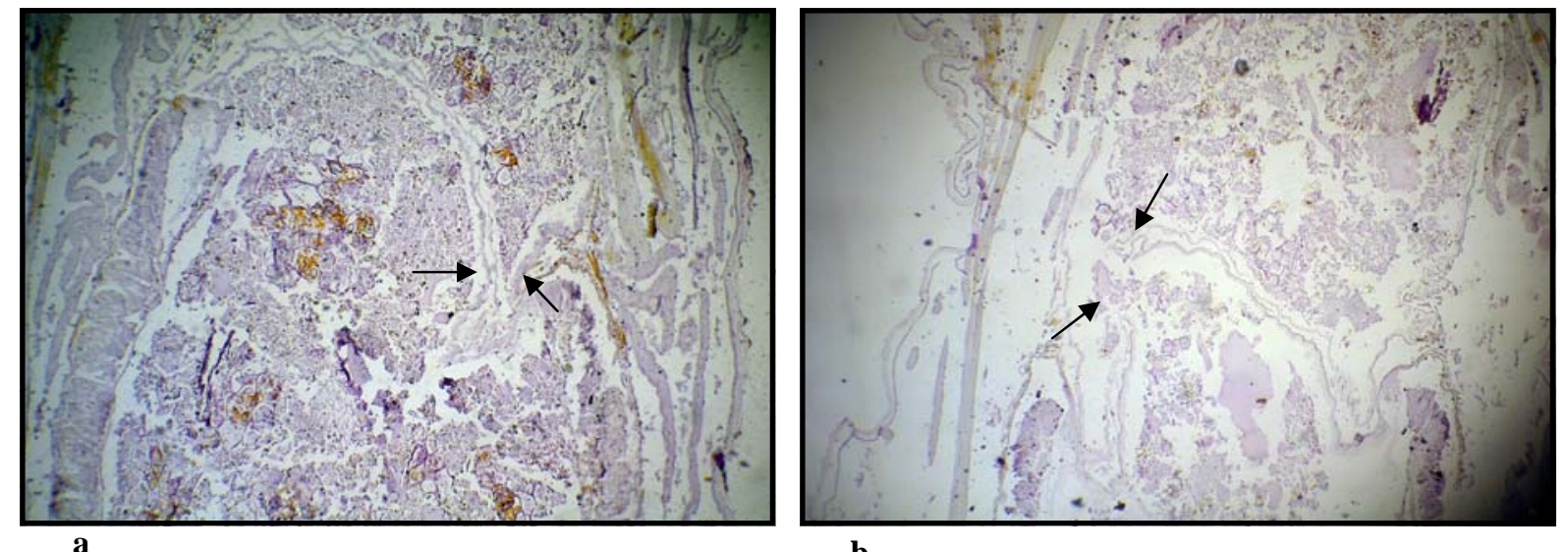

b

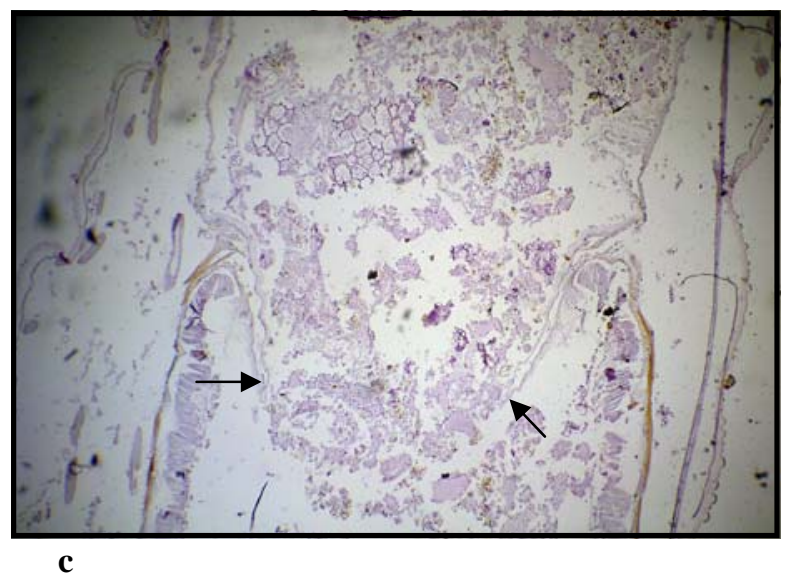

Plate 2: Longitudinal section through cardiac sphinictor region of last instar larvae,

Agrotis ipsilion, diet of the larvae had been treated with Melia azedarach extract a- control.

b- treated with $1.0 \mathrm{ppm}$

c- treated with $50 \mathrm{ppm}$

arrows indicate to the spinictor valvae

Longitudinal sections of treated larvae with A. altissima extract were showed the same effect of M. azedarach.

Effect on larvae midgut

In the application with $M$. azedarach and A. altissima extracts, the chinaberry extract was found more effective than the extract of tree of heaven. Sections of the midgut of black cutworm treated larvae explains the effect of $M$. azedarach extract which was took place by two ways: firstly, the extract was separated the peritrophic membrane and dissociated circulure and longitudinal muscles, therefore, M. azedarach was caused disruption of peristaltic and diastolic movement of the digative tract and the epithelia of the midgut was physically separated away than food materials (Plate 3). Secondly, M. azedarach was affected as antifeedant, especially at high the concentrations were used (Plate 3E). Schmidt

(1997) and Al-Hamadani (2002) were studied the effect of M. azedarach on Spodoptera exigua, S. littoralis and A. ipsilon. 
The peritrophic membrane of treated larvae with A. altissima was densely stained with AF stain (Plate 3D) in relation to peritrophic membrane of normal larva (plate 3A), therefore, the permeability and food absorption were significantly reduced.

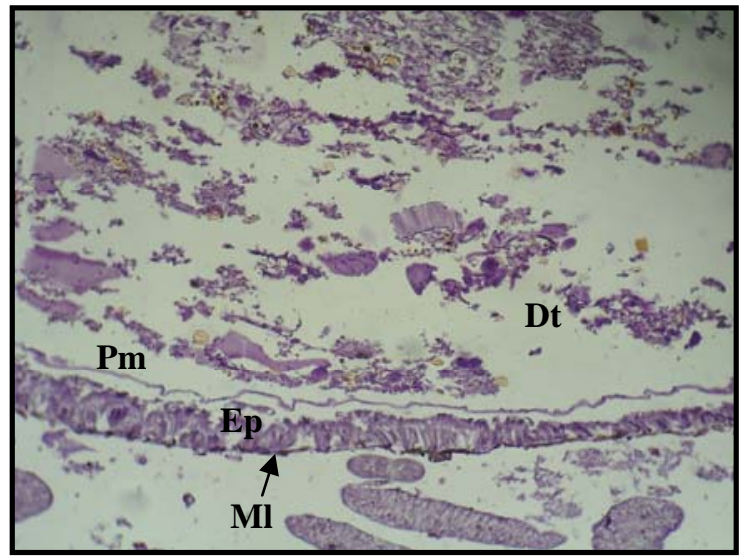

A

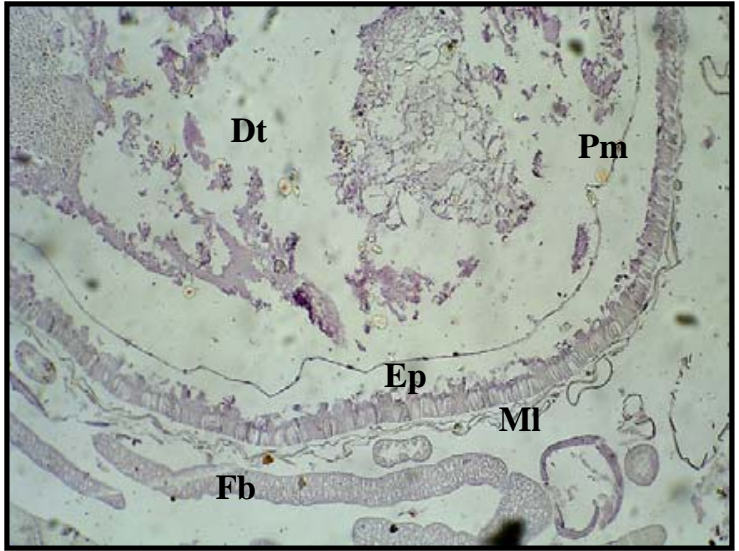

$\mathbf{B}$

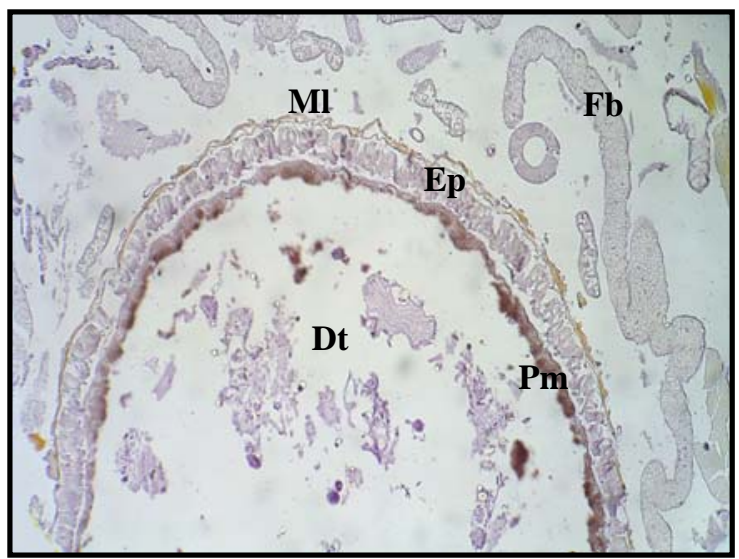

D

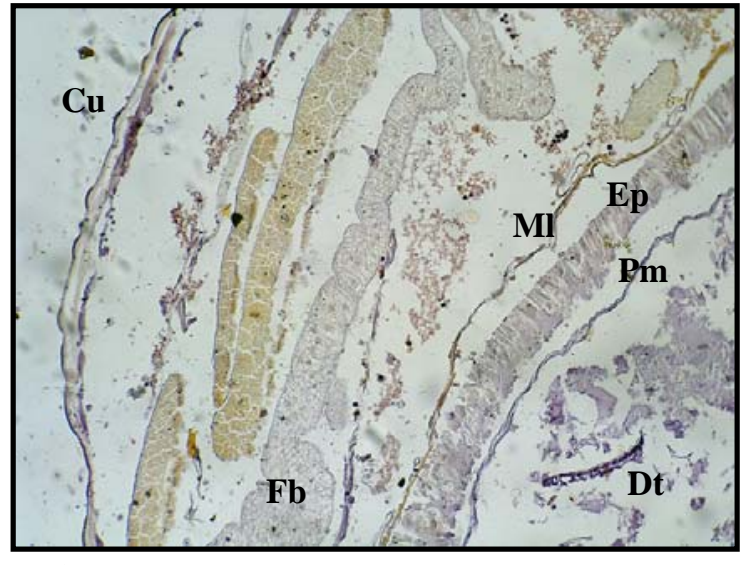

C

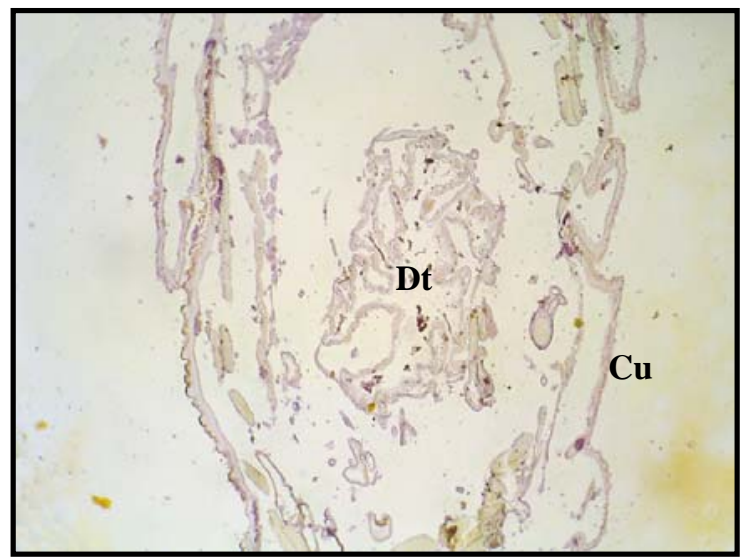

E

Plate 3: Effect of Melia azedarach and Ailanthus altissima extracts on midgut of Agrotis ipsilon larvae A- Control, B- Diet treated with 5 ppm,

C- Diet treated with $10 \mathrm{ppm}$,

$\mathrm{D}$ and E- Diet treated with $50 \mathrm{ppm}$,

Note: B,C and E- The extract of M. azedarach. Extract for D was A. altissima.

$\mathrm{Dt}=$ digestive tract, $\mathrm{Cu}=$ cuticle, $\mathrm{Ep}=$ epithelia, $\mathrm{Fb}=$ fat bodies,

$\mathrm{Ml}=$ muscular layer and $\mathrm{Pm}=$ peritrophic membrane. 


\section{REFERENCES}

Alche, L.E., Ferek, G.A.; Meo, M., Coto, C.E. and Maier, M.S., 2003. An Antiviral Meliacarpin from Leaves of Melia azedarach L. Z. Naturforsch, 58c: pp.215-219.

Al-Hamadani, M.A., 2002. Effect of some Neem Products, Azadirachta indica A. Juss and Fruit Extract of the Chinaberry Tree, Melia azedarach L. on some Physiological Aspects of the Beet Armyworm. Spodoptera exigua Hubner (Lepidoptera: Noctuidae). Ph.D. Thesis, Mosul University, Mosul-Iraq, 134p.

Aono, H., Kanecko, J. and Ohmots, T., 1999. Alkaloids and Quassinoids from Ailanthus malabariea. Phytochem., 37: pp.579-584.

Ascher, K.R.S., Schmutterer, H.; Zebits, C.P.W. and Naqvi, S.N.H., 1995. The Persian Llilac or Chinaberry Tree: Melia azedarach L., pp.605-642. In: H. Schmutterer (ed.), The Neem Tree, Azadirachta indica A. Juss and other Meliaceous Plants. Sources of Unique Natural Products for Integrated Pest Management, Medicine, Industry and other Purposes. VCH, Weinhiem, Germany, 696 p.

Barnby, M.A. and Klocke, J.A., 1996. Effects of Azadirachtin on Levels of Ecdysteroids and Prothoracicotropic Hormone-Like Activity in Heliothis virescens (Fabr.) Llarvae. J. Insect. Physiol., 36(2): pp.122-131.

Begleg, T. P.; Means, A. R.; O’Malley, B.W.; Riddiford, L. and Tashjion, A. H., 2005. Vitamins and Hormones, Vol. 73, Elsevier Isc. 288p.

Cabral, M.M.; Garcia, E.S.; Rembald, H.; De Simone and Kelecom, A., 1996. Antimoulting Activity in Brazilian Melia azedarach. Mem Inst. Oswaldo Crug, Rio de Janeiro, 91(1): pp.117-118.

Carpinella, M.; Defago, M.; Valladares, G. and Palacios, S.M., 2003. Antifeedant and Insecticide Properties of a Limonoid from Melia azedarach (Meliaceae) with Potential use for pest Management. J. Agric. Food chem., 51(2): pp.369-374.

Casinovi, C.G.; Ceccherelli, P.; Fardella, G. and Grandolini, G., 1983. Isolation and Structure of a Quassinoid from Ailanthus glandulosa. Phytochem., 22: pp. 28712873.

Cespedes, C.L.; Calderon, J.S.; Lina, L. and Arada, F., 2000. Growth Inhibitory Effects on Fall Armyworm, Spodoptera frugiperda of some Limonoids Isolated from cedrel spp. Meliaceae, J.A. Food Chem., 48(5): pp.1903-1908.

De'Souza, A.P. and Vendramim, J.D., 2000. Effect of Aqueous Exctracts of Melaceous Plants on Bemisia tabaci B Biotype on Tomato Plants. Bragantia, Campinas, 59(2): pp.173-179.

Ewen, A.B., 1962. An Improved Aldehyde Fuchsin Staining Technique for Neurosecretory Products in Insects. Trans. Amer. Micros. Soc., 81: pp.94-96.

Heisey, R.M. 1996. Identification of an Allelopathic Compounds from Ailanthus altissima and Characterization of its Herbicidal Activity. Amer. J. Botany, 83: pp.192-200.

Huang, R.G.; Zhou, J.; Suenage, H.; Takezaki, K.; Tadera, K. and Nakatani, M., 1995. Insect Antifeeding Property of Limonoids from Okinawa and Chinese Melia azedarach L., and from Melia toosendan (Meliaceae). Biosci. Biotech. Biochem., 59(9): pp.1955-1757. 
Mekhlif, A.F., 2004. Effect of Chinaberry Tree, Melia azedarach L. Extract on the Reproduction and Development of the Beet Armyworm Spodoptera exigua (Hub.) Lepidoptera Noctuidae. Ph.D. Thesis, Mosul University, Mosul-Iraq, 93p.

Nakatani, M.; Huang, R.C.; Okamura, H.; Iwagwa, T. and Tadera, K., 1998. Degraded Limonoids from Melia azedarach. Phytochem., 29: pp.425-427.

Richards, O.W. and Davies, R.G., 1978. Imms' Outlines of Entomology. Chapman and Hall, London and New York, $254 \mathrm{p}$.

Sandor, J. and Vera, C., 1979. Icongaphia Florae Parties Austro-orientalis Europae Centralis. Academia Kiado. Budapest, 704 p.

Schmidt, G.H., Ahmed, A.A. and Breuer, M., 1997. Effect of Melia azedarach on Larval Development and Reproduction Parameters of Spodoptera littoralis (Boisd) and Agrotis ipsilon (Hufn.) (Lep. Noctuidae). Anz. Schadlingskde ipfanzenschutz. Umweltschutz, 70: pp. 4-12.

Schmidt, G.H., Rembold, H., Ahmed, A.A. and Breuer, M., 1998. Effect of Melia azedarach Fruit Extract on Juvenile Hormone Titer and Protein Concentration in the Hemolymph of Two Species of Noctuid Lepidoptera larvae (Insecta: Lepidoptera: Noctuidae). Phytoparasitica, 26(4): pp.283-291.

Srivastava, S.K. and Gupta, H.O., 1985. New Limnoids from the Roots of Melia azedarach L. Indian J. Chem., 24B, pp.166-170.

Tsao, R., Romanchuk, F.E., Peterson, C.J. and Coats, J.R., 2002. Plant Growth Regulatory and Insecticidal Activity of Extracts of the Tree of Heaven (Ailanthus altissima). BMC Ecol., 2: 1p.

Wiltshire, E.P., 1957. The Lepidoptera of Iraq. Adlard and Son, Bartholomew Press, Dorking, $162 \mathrm{p}$.

Yang, R.Z. and Tang C.S., 1988. Plants used for Pest Control in Chinai, Literature Review. Econ. Bat., 42: pp.379-406. 